УДК 543.42:615.074:547.97:547.972:582.951.6

\title{
ХИМИЧЕСКИЙ АНАЛИЗ И СПОСОБ ПОЛУЧЕНИЯ НОВОЙ БИЛОГИЧЕСКИ АКТИВНОЙ КОМПОЗИЦИИ ИЗ ТРАВЫ АВРАНА ЛЕКАРСТВЕННОГО (GRATIOLA OFFICINALIS L.)
}

\author{
() Н.В. Полуконова", Н.А. Дурнова, М.Н. Курчатова, Н.А. Наволокин, А.Г. Голиков \\ Саратовский государственный медицинский университет \\ им. В.И. Разумовского, ул. Б. Казачья, 112, Саратов, 410012 (Россия), \\ e-mail:polukonovanv@yandex.ru
}

Описан способ экстракции из растительного сырья, позволяющий получать нетоксичную композицию биологически активных веществ из ядовитых растений, содержащих флавоноиды, на примере ядовитого растения аврана лекарственного (Gratiola officinalis L.). С увеличением процентного содержания этилового спирта (от 15\% к 96\%), используемого в качестве экстрагента, изменяется выход алкалоидов так, что экстракт, полученный $96 \%$-м этиловым спиртом, не дает положительной качественной реакции на содержание алкалоидов. Исследован химический состав экстракта с новой для аврана лекарственного нетоксичной биологически активной композицией. Установлено, что экстракт содержит неизвестный ранее для этого растения биофлавоноид - кверцетин. Среднее значение кверцетина в данном экстракте с использованием градуировочного графика стандартного образца кверцетина (98\%) Sigma составляет $0,66 \%$. Установленное нами методом жидкостной хроматографии (ВЭЖХ) количество кверцетина в сухом остатке экстрактивных веществ (получаемого из 10 г сухой травы аврана) составило 350 мкг.

Ключевые слова: авран лекарственный, химический состав, биофлавоноиды, способ экстракции, кверцетин.

\section{Введение}

В настоящее время достаточно эффективно исследуются способы получения биологически активных композиций (БАК) из сырья лекарственных растений с наименьшими побочными эффектами и вместе с тем с максимальным положительным фармакологическим действием. Авран лекарственный (Gratiola officinalis L.) - травянистое растение семейства Норичниковые, широко распространенное в Евразии и Северной Америке. Растение ядовито. Домашние животные распознают авран лекарственный и на пастбищах его не поедают, но это растение может попасть к ним вместе с сеном и вызвать отравление; особенно чувствительны к аврану лошади. Качество сырья аврана лекарственного регламентировано фармакопейной статьей 42-2358-85. Ранее трава аврана входила в состав сбора Здренко как симптоматическое средство при

Полуконова Наталья Владимировна - профессор кафедры общей биологии, фармакогнозии и ботаники, доктор биологических наук,

e-mail: polukonovanv@yandex.ru

Дурнова Наталья Анатольевна - заведующая кафедрой общей биологии, фармакогнозии и ботаники, доктор биологических наук, профессор,

e-mail: ndurnova@mail.ru

Курчатова Мария Николаевна - аспирантка, e-mail: kurchatova.marya@yandex.ru

Наволокин Никита Александрович - студент, e-mail: navolokin1@ rambler.ru

Голиков Алексей Геннадьевич - заведующий кафедрой фармацевтической химии, доктор химических наук, професcop, e-mail: golikov20@rambler.ru лечении папилломатозного гастрита и применялась как слабительное, антигельминтное, кардиотоническое, желчегонное и антисептическое средство $[1,2]$. В основном применялись водные настои травы и 15\%-я спиртовая настойка [2]. Полученные извлечения из травы аврана обладают достаточно высокой токсичностью, поэтому при внутреннем применении используются вместе со слизистыми отварами, с большой осторожностью и под обязательным врачебным контролем [3].

Разные способы экстракции из одного и того же растительного сырья могут приводить к получе-

\footnotetext{
* Автор, с которым следует вести переписку.
} 
нию БАК с разными химическим составом и свойствами [4]. Так, при получении экстракта из сырья аврана путем экстракции сырья 96\%-м этанолом (или метанолом, или н/(изо)-пропанолом) и хлороформом [5], в результате которого получается и используется хлороформная фракция с неполярными соединениями, включая ядовитые соединения (алкалоиды и гликозиды), экстрактивные вещества остаются токсичными. Кроме того, экстракт, полученный данным способом, обладает значительным слабительным эффектом, обусловленным содержанием в нем токсичных веществ - алкалоидов и гликозидов, оказывающих раздражающий эффект на кишечник, за счет чего резко снижается область его применения. Известны также способы получения водных настоев, спиртовой настойки и экстракта из сырья аврана, включающие использование этилового спирта разной концентрации и хлороформа, при которых экстракты из аврана содержат гликозиды грациозид (грациолин), грациотоксин, кукурбитациновый гликозид - элатерицид, жирное масло, сапонины, яблочную и бетулиновую кислоты, углеводы (стахиоза), терпеноиды (элатеризид, дезацетилэлатеринид, кукурбитацин Е и I), карденолиды, сапонины, флавоноиды (лигнозид, изолигнозид, апигенин, космосиин, лигнозид, аврозид, изоаврозид, неоаврозид, изонеоаврозид), а также алкалоиды $(0,2 \%)$ пока не установленного состава, в разном соотношении, в зависимости от способа выделения [3, 5, 6-9].

В настоящей работе анализируется экстракт, полученный новым, ранее не примененным для аврана способом, позволяющем получать нетоксичные экстрактивные вещества из ядовитых растений. Для данного экстракта из травы аврана нами уже описаны положительные эффекты на организм животных с перевиваемым раком печени и в то же время негативное воздействие на опухолевые клетки, проявляющееся как в виде цитотоксического, так и цитостатического эффекта [10-12].

Цель исследования - описать способ получения нетоксичного экстракта из травы ядовитого растения Gratiola officinalis L., содержащего биофлавоноиды, и провести химический анализ этого экстракта.

\section{Экспериментальная часть}

Для экстракции использовано сырье - трава аврана лекарственного (Gratiola officinalis L.), собранное на острове р. Волги у пос. Чардым (Саратовская обл.) в июне 2011 г. Исследования проводились с сухим сырьем в октябре 2011 г.

Для проведения качественных реакций использованы экстракты из травы аврана, полученные разными способами: 96\%-м этиловым спиртом; 70\%-м и 15\%-м этиловым спиртом, а также водный настой [13]. Для определения наличия флавоноидов использована проба Синода, проведена реакции с хлоридом алюминия, со щелочью и реакции на наличие алкалоидов: с реактивом Вагнера-Бушарда, с раствором 1\%-й пикриновой кислоты, с раствором кислоты фосфорномолибденовой, с кремневольфрамовой кислотой [13]. Для сравнения полученного нами 96\%-го спиртового экстракта из травы аврана лекарственного также использованы: водный настой, 15\%-я спиртовая настойка, экстракция 70\%-м этиловым спиртом [13].

Для установления химического состава использован экстракт из травы аврана, полученный $96 \%$-м этиловым спиртом. Суть данного способа заключается в использовании этилового спирта высокой концентрации в связи с относительно низкой температурой его кипения по сравнению с водой, что способствует лучшей сохранности флавоноидов в процессе экстрагировании сырья [13]. Подобранный нами способ экстракции включает также этап очистки от токсичных соединений (алкалоидов, гликозидов и др.), заключающийся в их растворении в хлороформе, центрифугировании и избавлении от хлороформной фракции [14]. Водная фракция высушивается в чашке Петри, что позволяет получить сухой остаток целевых продуктов и в дальнейшем дает возможность определять точную концентрацию целевых продуктов и рассчитывать точную дозировку для экспериментов, как in vitro, так и in vivo, а также позволяет длительное время хранить экстракт до начала применения [14].

Исследование химического состава 96\%-го спиртового экстракта аврана проводилось методом хромато-масс-спектрометром, модели Trace GC - Trace DSQ (фирма «ThermoFinnigan», CША). Были найдены оптимальные условия для разделения смеси анализируемых веществ в данном растворителе (этиловом спирте). Подвижная фаза: гелий, 99,995\% чистоты (скорость потока 1,2 мл/мин). Марка хроматографической колонки: Restek Stabilwax, 30 м, внутренний диаметр 0,25 мм, толщина фазы 0,25 мкм (колонка с неполярной неподвижной фазой на основе полиэтиленгиколя). Температурная программа: $150{ }^{\circ} \mathrm{C}$ при $\mathrm{t}=10$ мин, затем нагрев со скоростью $2{ }^{\circ} \mathrm{C} /$ мин до $240{ }^{\circ} \mathrm{C}$ в течение 10 мин, $\mathrm{t}$ инжектора $=290{ }^{\circ} \mathrm{C}, \mathrm{t}$ источника ионов $=220^{\circ} \mathrm{C}$. Сканирование проводили в интервале 45-400 а.е.м. (Full Scan), режим Splitless. MS Transfer Line $=250^{\circ} \mathrm{C}$. Время включения филамента через 5 мин после инжекции образца количеством 2 мкл. Используемые биб- 
лиотеки масс-спектров: Библиотека NIST 02 (Национальный Институт Стандартов и Технологий, США), Wiley. Распознавание обнаруженных соединений проводили путем сравнения полученных масс-спектров с масс-спектрами библиотек.

Определение количественного содержания кверцетина в 96\%-м спиртовом экстракте аврана проводили с помощью жидкостной хроматографии (ВЭЖХ) по стандартной методике проведения «Высокоэффективная жидкостная хроматография» на приборе «Стайер UV/VIS» (фирма «Аквилон») в изократическом режиме, со спектрофотометрическим детектором [15]. При количественном определении кверцетина использован стандартный образец кверцетина (98\%) фирмы Sigma.

Вещество в чашке Петри растворяли количественно 5 мл этилового спирта, после чего непосредственно перед хроматографированием разбавляли смесь в 10 и 20 раз. Хроматографирование проводили на градиентном ВЭЖX - приборе «Стайер UV/VIS» (фирма «Аквилон») в изократическом режиме, со спектрофотометрическим детектором. Длина волны 254 нм. Центр коллективного пользования разработал методику оптимального разделения и определения кверцетина в присутствии других флавоноидов и алкалоидов. Хроматографирование осуществляли в обращенно-фазовом изократическом режиме, подвижная фаза: изопропанол - вода = 30 : 70 (процент по объему), скорость потока 700 мкл/мин. Время удерживания кверцетина составило 7,65-7,75 мин. Колонка Phenomenex Luna 5U C18(2), размер пор $100 \AA$ А, длина $150 \times$ диаметр 4,60 мм, размер сорбента 5 micron. Проба, разбавленная в 20 раз.

\section{Результаты и обсуждение}

Нами проведены качественные реакции на наличие биофлавоноидов и алкалоидов в извлечениях из травы аврана лекарственного, полученных разными способами (табл. 1, 2). Интенсивность проявления окраски в разных качественных реакциях на биофлавоноиды увеличивалась от водного настоя к 15\%-й спиртовой настойке и экстрактам, полученным с использованием 70 и 96\%-го этилового спирта (табл. 1). В то время как появление осадка и изменение интенсивности окраски в разных качественных реакциях (табл. 1), свидетельствующее о наличии алкалоидов, наоборот, понижалось от водного настоя к 15\%-й настойке и экстрактам, полученным с использованием 70 и $96 \%$ этилового спирта.

В 96\%-м спиртовом экстракте аврана алкалоиды не обнаружены.

Таблица 1. Результаты специфических качественных реакций на биофлавоноиды в экстрактах из травы аврана лекарственного, полученных разными способами

\begin{tabular}{c|c|c}
\hline Извлечения & \multicolumn{2}{|c}{ Результаты качественных реакций } \\
\cline { 2 - 3 } из травы аврана & в пробе Синода & слоридом алюминия \\
\hline 1 & Интенсивное красно-коричневое окрашивание & Интенсивное лимонно-желтое окрашивание \\
\hline 3 & Слабое красно-коричневое окрашивание & Слабое лимонно-желтое окрашивание \\
4 & & \\
\hline
\end{tabular}

Примечания: цифрами обозначены: 1) экстракт, полученный 96\%-м этиловым спиртом, 2) водно-спиртовой экстракт, полученный 70\%-м этиловым спиртом, 3) 15\%-я спиртовая настойка, 4) спиртовой раствор водного настоя.

Таблица 2. Результаты качественных реакций на алкалоиды в извлечениях из травы аврана лекарственного, полученных разными способами

\begin{tabular}{|c|c|c|c|c|}
\hline \multirow{2}{*}{$\begin{array}{c}\text { Извлечения } \\
\text { из аврана }\end{array}$} & \multicolumn{4}{|c|}{ Результаты качественных реакций с } \\
\hline & $\begin{array}{c}\text { реактивом } \\
\text { Вагнера-Бушарда }\end{array}$ & $\begin{array}{c}\text { раствором } 1 \% \text { пикри- } \\
\text { новой кислоты }\end{array}$ & $\begin{array}{c}\text { раствором кислоты } \\
\text { фосфорномолибденовой }\end{array}$ & $\begin{array}{c}\text { кремневольфрамовой } \\
\text { кислотой }\end{array}$ \\
\hline 1 & \multicolumn{4}{|c|}{ Изменения отсутствовали } \\
\hline 2 & \multicolumn{4}{|c|}{ Изменения отсутствовали } \\
\hline 3 & $\begin{array}{c}\text { Выпадение } \\
\text { бурого осадка }\end{array}$ & $\begin{array}{c}\text { Пожелтение } \\
\text { и помутнение раствора }\end{array}$ & $\begin{array}{c}\text { Пожелтение раствора, } \\
\text { со временем перехо- } \\
\text { дящее в зеленое }\end{array}$ & Осветление раствора \\
\hline 4 & & & $\begin{array}{c}\text { Интенсивное желтое } \\
\text { окрашивание раствора, } \\
\text { со временем перехо- } \\
\text { дящее в зеленое }\end{array}$ & $\begin{array}{c}\text { Интенсивное осветле- } \\
\text { ние раствора }\end{array}$ \\
\hline
\end{tabular}

Примечания: цифрами обозначены: 1) экстракт, полученный 96\%-м этиловым спиртом, 2) водно-спиртовой экстракт, полученный 70\%-м этиловым спиртом, 3) 15\%-я спиртовая настойка, 4) спиртовой раствор водного настоя. 
Были проанализированы предложенный нами способ экстракции из травы аврана 96\%-м спиртом [14] и наиболее близкий к нему способ получения экстракта из аврана лекарственного путем экстракции измельченного сырья 96\%-м этанолом (или метанолом, или н/(изо)-пропанолом), удаления растворителя под вакуумом при температуре $80{ }^{\circ} \mathrm{C}$, нагревания остатка с растворителем (ароматическим или циклическим) или хлорированным растворителем (бензолом, толуолом, ксилолом, хророформом), удаления растворителя под вакуумом, растворения очищенного экстракта в воде при температуре 55-130 ${ }^{\circ} \mathrm{C}$, охлаждения, обработки метилэтилкетоном, фильтрования, удаления растворителя дистилляцией под вакуумом [5] (табл. 3). Токсичность экстракта аврана, полученного указанным способом, по мнению авторов патента, снижена, но экстракт обладает сильным слабительным и спазмолитическим действием [5].

Наиболее значимые отличия сравниваемых способов получения экстрактов заключаются в трех действиях: «4», «6» и «7» (табл. 3). В действии «4» приготовление экстракта в противопоставленном способе происходит не только с добавлением растворителя, но и кипячением полученного раствора не указанное в патенте количество времени, из чего следует, что время кипячения не влияет на выход целевых продуктов. В то время как в нашем способе экстракция путем кипячения в 96\%-м этиловом спирте (температура его кипения, как известно, $78{ }^{\circ} \mathrm{C}$ ) длится строго 15 мин (т.к. при более длительном кипячении происходит разрушение целевых продуктов).

Таблица 3. Сопоставительный анализ предложенного и противопоставленного способов экстракции из травы аврана лекарственного

\begin{tabular}{|c|c|c|}
\hline Этапы & Противопоставленный способ & Предложенный нами способ \\
\hline 1 & \multicolumn{2}{|c|}{ Измельчение сырья } \\
\hline 2 & Экстракция спиртом 96\%-м путем кипячения & $\begin{array}{l}\text { Экстракция спиртом 96\%-м на водяной бане, путем } \\
\text { доведения до кипения и кипячения в течение 14- } \\
15 \text { мин. Фильтрование полученного экстракта и тща- } \\
\text { тельный отжим экстрагируемого сырья для удаления } \\
\text { крупных балластных частиц }\end{array}$ \\
\hline 3 & $\begin{array}{l}\text { Выпаривание экстракта методом дистилляции } \\
\text { или перегонки в вакууме }\end{array}$ & $\begin{array}{l}\text { Выпаривание досуха в термостате при температуре не } \\
\text { выше } 55-60^{\circ} \mathrm{C}\end{array}$ \\
\hline 4 & $\begin{array}{l}\text { Растворение полученного экстракта ароматиче- } \\
\text { скими или ациклическими углеводородами или } \\
\text { хлорированными растворителями с последую- } \\
\text { щим кипячением данного раствора }\end{array}$ & $\begin{array}{l}\text { Добавление к выпаренному экстракту дистиллирован- } \\
\text { ной воды } 40-50 \text { C (4/5 части от общего объема), тща- } \\
\text { тельное растворение сухого экстракта. } \\
\text { Добавление к водному раствору сухого экстракта хло- } \\
\text { роформа ( } 1 / 5 \text { части от общего объема) для растворе- } \\
\text { ния токсичных соединений (алкалоидов, гликозидов). } \\
\text { Все манипуляции проводятся при температуре не вы- } \\
\text { ше 55-60 ㄷ }\end{array}$ \\
\hline 5 & Отсутствует & $\begin{array}{l}\text { Центрифугирование водно-хлороформного раствора } \\
\text { сухого экстракта в течение } 15 \text { мин при скорости } 1500 \\
\text { оборотов в минуту, что в короткий срок позволяет } \\
\text { получить наиболее полное разделение на водную } \\
\text { фракцию целевых продуктов и хлороформную фрак- } \\
\text { цию токсичных продуктов, содержащих неполярные } \\
\text { примеси, такие как хлорофилл и др., а также алкалои- } \\
\text { ды и гликозиды }\end{array}$ \\
\hline 6 & $\begin{array}{l}\text { Удаление растворителя (хлороформа) из горячего } \\
\text { раствора при температуре } 80 \text { C путем использо- } \\
\text { вания вакуума. Экстрагирование алканолом с } 4 \\
\text { до } 5 \text { атомов углерода, или диалкилом кетоном, } \\
\text { имеющим всего от } 4 \text { до } 6 \text { атомов углерода }\end{array}$ & $\begin{array}{l}\text { Удаление хлороформной фракции вместе с неполяр- } \\
\text { ными примесями (хлорофилла) и др., а также алкалои- } \\
\text { дами и гликозидами. Все длительные манипуляции } \\
\text { проводятся при температуре не выше } 55-60 \text { C }\end{array}$ \\
\hline 7 & $\begin{array}{l}\text { Отделение органической фазы от водной путем } \\
\text { декантации или вакуумом, в дальнейшем исполь- } \\
\text { зуется органическая фаза и удаление растворите- } \\
\text { ля полностью из органической фазы, соответст- } \\
\text { венно азеотропной дистилляцией, оставляя оса- } \\
\text { док, который называется очищенный экстракт }\end{array}$ & В дальнейшем используется водная фаза \\
\hline 8 & $\begin{array}{l}\text { Получается жидкий остаток, содержащий алка- } \\
\text { лоиды и гликозиды и не содержащий флавоноиды }\end{array}$ & $\begin{array}{l}\text { Высушивание водной фракции в чашке Петри, что } \\
\text { позволяет получить сухой остаток целевых продуктов }\end{array}$ \\
\hline
\end{tabular}


На этапах «6» и «7» (табл. 3) в противопоставленном нашему способе путем испарения удаляют хлороформ без удаления алкалоидов и гликозидов, с помощью которого они были выделены, и в дальнейшем работают с органической фракцией, содержащей данные токсические соединения и не содержащей флавоноиды, т. к. их большая часть разрушилась на предыдущих этапах. В то время как в нашем способе алкалоиды и гликозиды, содержащиеся в хлороформной фракции, полученной путем центрифугирования (на 1500 оборотов), удаляются.

В итоге получается экстракт в виде сухого остатка, что позволяет оценивать его концентрацию, а в противопоставленном способе добавляются спирты и эфиры и на выходе получается жидкий экстракт, в котором затруднено определение концентрации.

Указанные нами отличия способов сказываются на конечном продукте, что подтверждается и разными их биологическими свойствами. Так, хотя в противопоставленном способе и указывается, что полученный экстракт обладает сниженной токсичностью, его $\mathrm{LD}_{50}$ для крыс составляет при пероральном введении 600 мг/кг [7], а экстракт, полученный заявленным нами способом, даже при более биодоступном введении, внутрибрюшинном (т.е. 100\% попадании в кровоток) - 1663 мг/кг не вызывает гибели ни одного животного $[5,11]$. Вышеизложенное свидетельствует о гораздо более высокой токсичности экстракта, полученного противопоставленным способом, и низкой токсичности полученного нами экстракта. Следовательно, экстракты, полученные сравниваемыми способами, представляют собой разные биологические активные композиции с разными классами токсичности [5, 10-12].

Помимо разных классов токсичности, сравниваемые биологически активные композиции обладают и разным действием. Так, противопоставленный экстракт обладает выраженным слабительным эффектом [5], которым обладает и отвар из аврана, что обусловлено содержащимися в нем токсичными веществами (алкалоидами и гликозидами), оказывающими раздражающий эффект на кишечник, и не обладает общим благоприятным влиянием на организм животных, в отличие от экстракта, полученного нами способом [5, 10-12].

Из экстракта аврана, полученного 96\%-м этиловым спиртом, были выделены органические вещества, вероятность обнаружения которых соответствует параметрам «превосходное и хорошее соответствие» (табл. 4, рис. 1). В результате проведенного исследования нами впервые обнаружено, что среди флавоноидов аврана присутствует также и кверцетин (рис. 2). Среднее значение кверцетина в данном экстракте с использованием градуировочного графика стандартного образца кверцетина (98\%) Sigma составляет 0,66\%. Установленное нами методом жидкостной хроматографии (ВЭЖХ) количество кверцетина в сухом остатке экстрактивных веществ (получаемого из 10 г сухой травы аврана) составило 350 мкг.

Таблица 4. Содержание веществ в экстракте из травы аврана лекарственного, полученном 96\%-м этиловым спиртом

\begin{tabular}{|c|c|c|}
\hline Название вещества & $\begin{array}{c}\text { Молекуляр- } \\
\text { ный вес }\end{array}$ & $\begin{array}{c}\text { Брутто формула } \\
\text { соединения }\end{array}$ \\
\hline 4-vinyl-2-methoxyphenol (4-винил-2-метоксифенол) & 150 & $\mathrm{C}_{9} \mathrm{H}_{10} \mathrm{O}_{2}$ \\
\hline 4H-Pyran-4-one, 2,3-dyhydro-3,5-dihydroxy-6-methyl & 144 & $\mathrm{C}_{6} \mathrm{H}_{8} \mathrm{O}_{4}$ \\
\hline (2,3-дигидро-3,5-дигидрокси-6-метил-4Н-пиран-4-ОН) & & \\
\hline 2,3-dihydrobenzofuran (2,3-дигидробензофуран) & 120 & $\mathrm{C}_{8} \mathrm{H}_{8} \mathrm{O}$ \\
\hline 3-Furoic acid (3-фуранкарбоновая кислота) & 112 & $\mathrm{C}_{5} \mathrm{H}_{4} \mathrm{O}_{3}$ \\
\hline 2-Furancarboxaldehyde, 5-(Hydroxymethyl), (5-гидроксиметил-2-фуральдегид) & 126 & $\mathrm{C}_{6} \mathrm{H}_{6} \mathrm{O}_{3}$ \\
\hline Ethyl- $\alpha$-d-riboside (этил- $\alpha$-d-рибозид) & 178 & $\mathrm{C}_{7} \mathrm{H}_{14} \mathrm{O}_{5}$ \\
\hline 4-propylphenol (4-пропилфенол) & 136 & $\mathrm{C}_{9} \mathrm{H}_{12} \mathrm{O}$ \\
\hline Pyrocatechol (пирокатехин) & 110 & $\mathrm{C}_{6} \mathrm{H}_{6} \mathrm{O}_{2}$ \\
\hline L-luxose (pentose) (L-луксоза (пентоза) & 150 & $\mathrm{C}_{5} \mathrm{H}_{10} \mathrm{O}_{5}$ \\
\hline 6-Deoxyhexose L-galactose, 6-deoxy (6-деоксигексоза L-галактоза) & 164 & $\mathrm{C}_{6} \mathrm{H}_{12} \mathrm{O}_{5}$ \\
\hline 4-Hydroxy-3-methoxyphenylethyl alcohol (Бензоилуксусной кислоты этиловый эфир) & 168 & $\mathrm{C}_{9} \mathrm{H}_{12} \mathrm{O}_{3}$ \\
\hline Hexadecanoic Acid (Palmitic Acid) & 256 & $\mathrm{C}_{16} \mathrm{H}_{32} \mathrm{O}_{2}$ \\
\hline Гексадекановая кислота (Пальмитиновая кислота) & & \\
\hline Homovanillic acid (Гомованилиновая кислота) & 182 & $\mathrm{C}_{9} \mathrm{H}_{10} \mathrm{O}_{4}$ \\
\hline D-allose (глюкоза) & 180 & $\mathrm{C}_{6} \mathrm{H}_{12} \mathrm{O}_{6}$ \\
\hline d-Mannitol, 1,4-anhydro- (1,4-ангидро- d-маннитол) & 164 & $\mathrm{C}_{6} \mathrm{H}_{12} \mathrm{O}_{5}$ \\
\hline Benzoic Acid Retardex (Бензойная кислота) & 122 & $\mathrm{C}_{7} \mathrm{H}_{6} \mathrm{O}_{2}$ \\
\hline Кверцетин & 302.2 & $\mathrm{C}_{15} \mathrm{H}_{10} \mathrm{O}_{7}$ \\
\hline
\end{tabular}


<smiles>C=Cc1ccc(O)c(OC)c1</smiles>

4-vinyl-2-methoxyphenol<smiles>O=C(O)c1ccoc1</smiles>

3-Furoic acid<smiles>CC(O)C(O)C(O)C(O)C=O</smiles>

6-Deoxyhexose L-galactose, 6-deoxy<smiles>CCCc1ccc(O)cc1</smiles>

4-propylphenol<smiles>O=CC(O)C(O)C(O)C(O)CO</smiles>

D-allose<smiles>O=c1c(O)c(-c2ccc(O)c(O)c2)oc2cc(O)cc(O)c12</smiles>

Кверцетин<smiles>CCOC1OC(CO)C(O)C1O</smiles>

Ethyl- $\alpha$-d-riboside<smiles>O=Cc1ccc(CO)o1</smiles>

2-Furancarboxaldehyde, 5(Hydroxymethyl)<smiles>Oc1ccccc1O</smiles>

Pyrocatechol<smiles>COCc1cc(CCO)ccc1O</smiles>

4-Hydroxy-3-methoxyphenylethyl alcohol

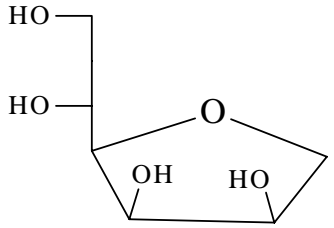

d-Mannitol, 1,4-anhydro-<smiles>c1ccc2c(c1)CCO2</smiles>

2,3-dihydrobenzofuran<smiles>CC1=C(O)C(=O)C(O)CO1</smiles>

4H-Pyran-4-one, 2,3-dyhydro-3,5dihydroxy-6-methyl<smiles>O=CC(O)C(O)C(O)CO</smiles>

L-luxose (pentose)<smiles>COc1cc(CC(=O)O)ccc1O</smiles>

Homovanillic acid<smiles>O=C(O)c1ccccc1</smiles>

Benzoic Acid Retardex<smiles>CCCCCCCCCCCCCCCC(=O)O</smiles>

Hexadecanoic Acid (Palmitic Acid)

Рис. 1. Формулы веществ, выявленных в экстракте аврана лекарственного

В результате нами разработан способ получения сухого экстракта из травы аврана лекарственного, содержащего новую, ранее не известную для данного растения биологически активную композицию. Новая композиция включает сумму флавоноидов, в т.ч. и кверцетин, и лишена токсических соединений - алкалоидов и гликозидов, о чем свидетельствует то, что даже высокие дозировки полученного нами экстракта не вызывают посинения губ, удушья, остановки сердца крыс [12, 16-19]. Кроме того, полученная нами БАК обладает новыми свойствами, в частности антиоксидантным, противоопухолевым и др. [5, 10-12], среди которых отсутствуют такие, как слабительное, рвотное, спазмолитическое, диуретическое, дигиталисоподобное на сердце. 


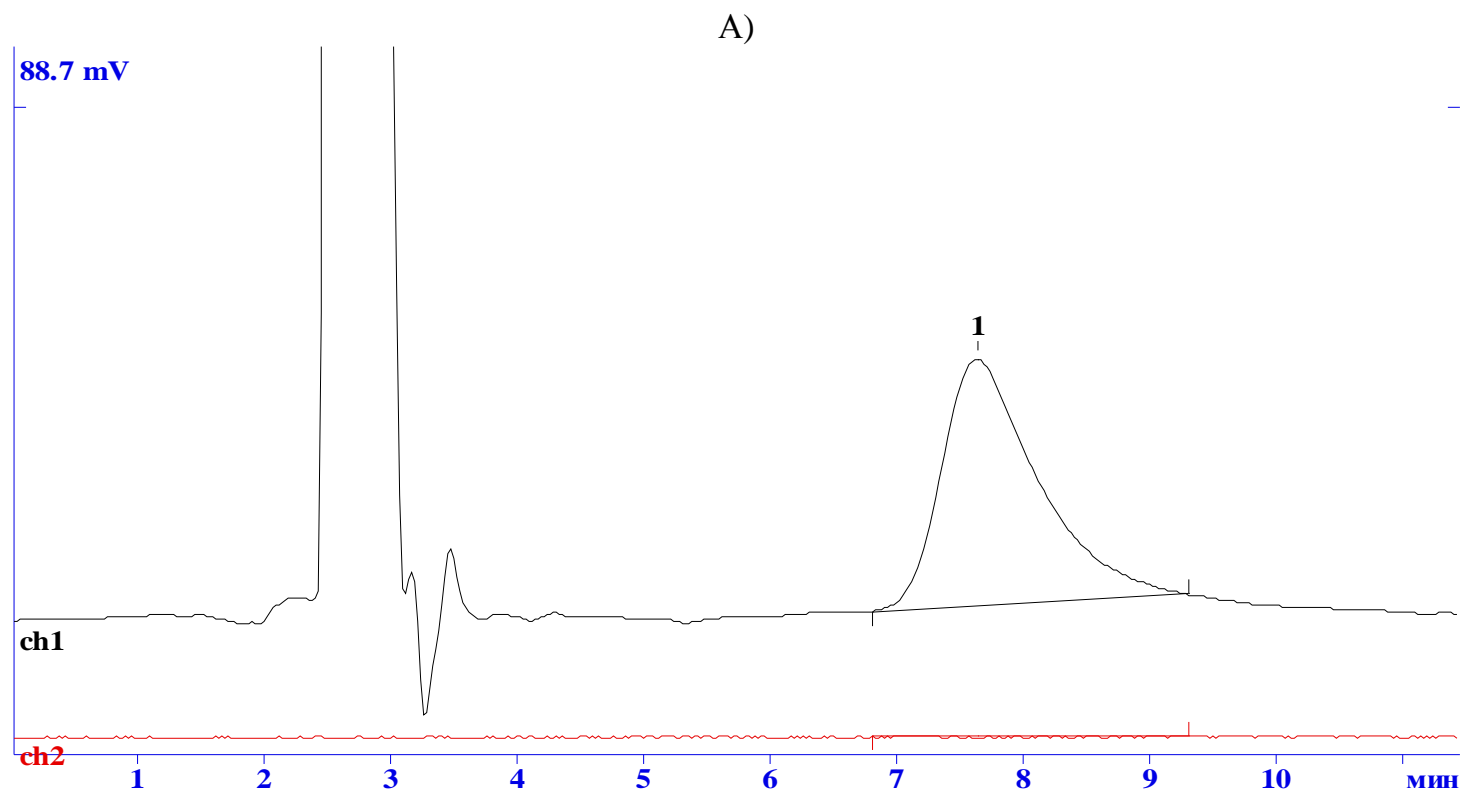

Б)

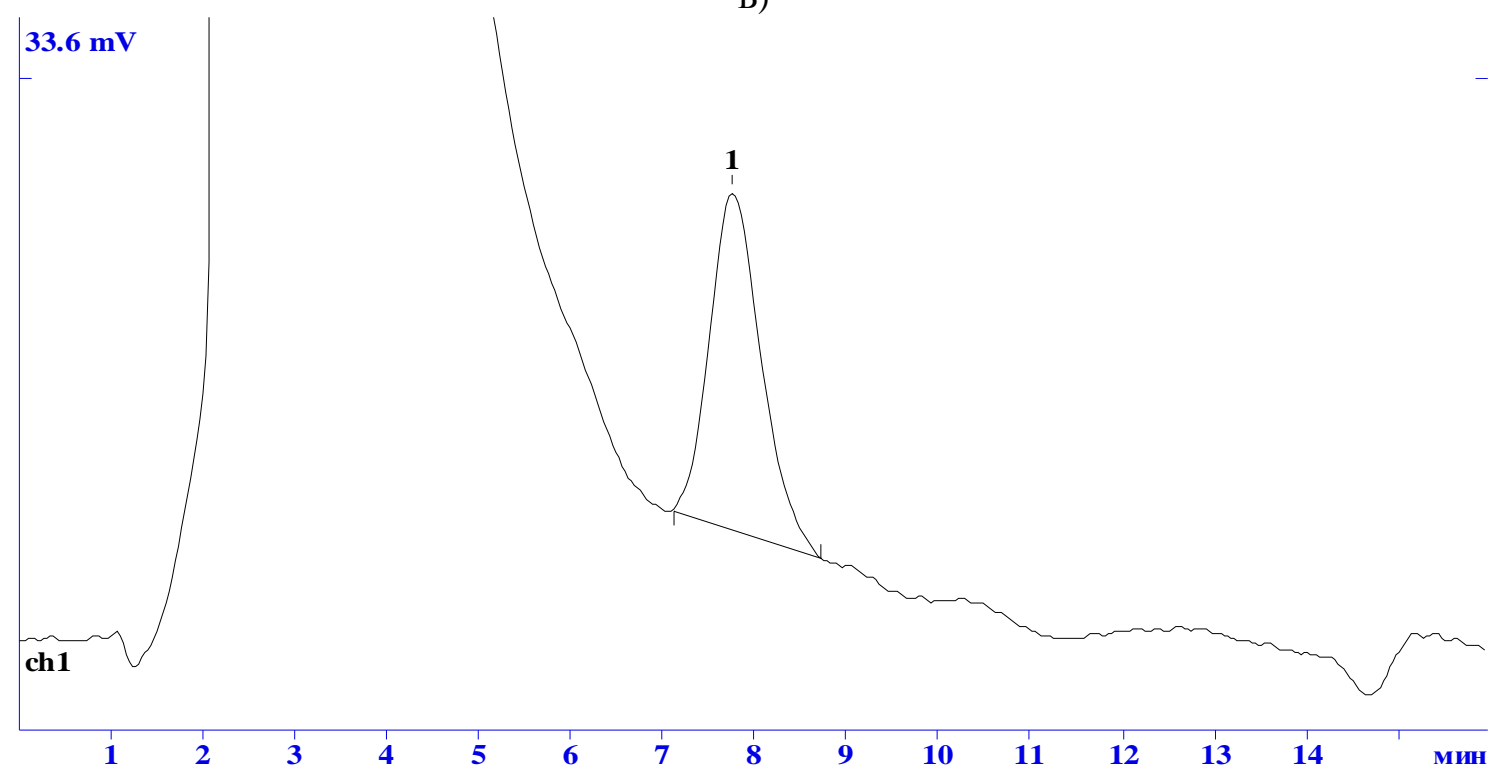

Рис. 2. Хроматограммы: А - анализируемого раствора (проба, разбавленная в 20 раз), Б - модельного раствора кверцетина, в концентрации - 10 мкг/мл

\section{Выводы}

В полученном нами 96\%-м спиртовом экстракте аврана выявлен отрицательный результат качественных реакций на алкалоиды, что объясняет отсутствие токсических эффектов при его использовании в экспериментах с лабораторными животными.

Новая для аврана лекарственного нетоксичная биологически активная композиция содержит флавоноид - кверцетин, не обнаруженный ранее в сырье аврана. Среднее значение кверцетина в данном экстракте с использованием градуировочного графика стандартного образца кверцетина (98\%) Sigma составляет около 0,66\%. Установленное нами методом жидкостной хроматографии (ВЭЖХ) количество кверцетина в сухом остатке экстрактивных веществ (получаемого из 10 г сухой травы аврана) составило 350 мкг.

Полученный данным способом экстракт из травы аврана лекарственного может быть рекомендован для дальнейшего изучения его биологических свойств. 


\section{Список литературы}

1. Государственная фармакопея СССР. М., 1989. Вып. 2. 400 с.

2. http://www.dorogaistin.ru

3. http://www.travolekar.ru/articles.php

4. Пономарев В.Д. Экстрагирование лекарственного сырья. М., 1976. 186с.

5. Patent 196400488251063118 (GB). Plant extract / M.J. Le. 1967.

6. Patent 5804575 (US). Methods of manufacturing betulinic acid / Pezzuto Dg., Darrick S.H.L. Kim. 1997.

7. Ruzicka L., Lamberton A.H., Christe Ruzicka C.W. Synthetic approach to betulinic acid // Helv. Chim. Acta. 1938. Vol. 21. Pp. 1706-1717.

8. Куркин В.А. Фармакогнозия : учебник для студентов фармацевтических вузов. Самара, 2004. 1180 с.

9. Алефиров А.Н. Фитотерапия против онкологии. СПб., 2010. 240 с.

10. Полуконова Н.В., Меркулова Е.П., Дурнова Н.А., Романтеева Ю.В., Бородулин В.Г. Изучение антиоксидантной активности экстракта аврана лекарственного на крысах с перевитой опухолью печени РС-1 // Биологически активные вещества: фундаментальные и прикладные вопросы получения и применения : тез. докл. научн.-практ. конф. Киев, 2011. С. 585.

11. Наволокин Н.А., Павлова А.В. Морфологические изменения в мышцах у лабораторных крыс и определение токсичности при введении экстракта аврана // Бюллетень медицинских Интернет-конференций. 2012. Вып. 2. C. $82-83$.

12. Navolokin N.A., Polukonova N.V., Maslyakova G.N., Bucharskaya A.B., Durnova N.A. Effect of extracts of Gratiola officinalis and Zea mays on the tumor and the morphology of the internal organs of rats with trasplanted liver cancer // Russian Open Medical Journal. 2012. Vol. 1, N2. C. 0203. URL: http://www.romj.org/2012-0203.

13. Государственная фармакопея РФ. М., 2008. 704 с.

14. Патент 2482863 (РФ). Способ получения сухого экстракта из растительного сырья, обладающего биологической активностью / Н.В. Полуконова, Н.А. Наволокин, Н.А. Дурнова, Г.Н. Маслякова, А.Б. Бучарская. 2013.

15. Золотов Ю.А. Аналитическая химия: фрагменты картины. М., 1999. 144 с.

16. Байтман Т.П., Наволокин Н.А. Влияние экстракта аврана лекарственного на лабораторных животных с перевитой саркомой S-45 // Бюллетень медицинских Интернет-конференций. 2013. Т. 3, №2. С. 374.

17. Navolokin N.A., Polukonova N.V., Bucharskaya A.B., Maslyakova G.N. Morphofunctional changes in laboratory rats with transplanted liver cancer PC-1 after prolongated per-oral administration of flavonoid containing extracts // Вестник российского государственного медицинского университета. 2012. Вып. 1. С. 277-278.

18. Наволокин Н.А., Полуконова Н.В., Маслякова Г.Н., Бучарская А.Б, Дурнова Н.А. Морфология внутренних органов и опухоли лабораторных крыс с перевитым раком печени Рс-1 при пероральном введении флавоноидсодержащих экстрактов аврана лекарственного (Gratiola officinalis L.) и кукурузы антоциановой (Zea mays L.) // Саратовский научно-медицинский журнал. 2013. Т. 9, №2. С. 213-220.

19. Наволокин Н.А., Полуконова Н.В., Маслякова Г.Н., Скворцова В.В., Байтман Т.П., Бучарская А.Б., Дурнова Н.А. Противоопухолевая активность растительных экстрактов, содержащих биофлавоноиды // Российский биотерапевтический журнал. 2013. Т. 12, №2. С. 59-59а.

Поступило в редакциию 28 февраля 2013 г.

После переработки 16 ноября 2013 г. 
Polukonova N.V., Durnova N.A., Kurchatova M.N., Navolokin N.A., Golikov A.G. CHEMICAL ANALYSIS OF THE NEW BIOLOGICAL ACTIVE COMPOSITION FROM MEDICATIVE HERB HEDGE-HISSOP (GRATIOLA OFFICINALIS L.)

Saratov State Medical University named after V.I. Razumovsky, Bolshaya Kazachia st., 112, Saratov, 410012 (Russia), e-mail: e-mail: polukonovanv@yandex.ru

The method of extraction from vegetable raw materials, allowing to receive non-toxic composition of biologically active substances from poisonous plants containing flavonoids, for example, poisonous plant coast of Gratiola officinalis L. The increase of the percentage content of ethyl alcohol (from 15 to 96\%), used as a solvent, output changes alkaloids so that the extract obtained $96 \%$ ethanol does not provide for positive qualitative reaction on the content of alkaloids. Investigated the chemical composition of the extract of the coast of Gratiola officinalis non-toxic, biologically active composition. It is established that the extract contains a previously unknown to this plant bioflavonoid - quercetin. The average value of quercetin in this extract, using the calibration curve of the standard sample quercetin (98\%) Sigma, is $0.66 \%$. Established by liquid chromatography (HPLC) number of quercetin in the dry residue of the extractive substances (gained from $10 \mathrm{~g}$ of dry grass coast of Gratiola officinalis) amounted to $350 \mathrm{mcg}$.

Keywords: Gratiola officinalis L., hyssop, bioflavonoids, chemical composition, extraction method, Quercetin.

\section{References}

1. Gosudarstvennaia farmakopeia SSSR. [USSR]. Moscow, 1989, no. 2, 400 p. (in Russ.).

2. http://www.dorogaistin.ru (in Russ.).

3. http://www.travolekar.ru/articles.php (in Russ.).

4. Ponomarev V.D. Ekstragirovanie lekarstvennogo syr'ia. [Extraction of crude drug]. Moscow, 1976, 186 p. (in Russ.).

5. Patent 196400488251063118 (GB). 1967.

6. $\quad$ Patent 5804575 (US). 1997.

7. Ruzicka L., Lamberton A.H., Christe Ruzicka C.W. Helv. Chim. Acta, 1938, vol. 21, pp. 1706-1717.

8. Kurkin V.A. Farmakognoziia. [Pharmacognosy]. Samara, 2004, 1180 p. (in Russ.).

9. lefirov A.N. Fitoterapiia protiv onkologii. [Herbal medicine against cancer.]. St. Petersburg, 2010, 240 p. (in Russ.).

10. Polukonova N.V., Merkulova E.P., Durnova N.A., Romanteeva Iu.V., Borodulin V.G. Biologicheski aktivnye veshchestva: fundamental'nye i prikladnye voprosy polucheniia i primeneniia: tezisy dokladov nauchno-prakticheskoi konf. [Biologically active substances: fundamental and applied to obtain and use: Abstracts of scientific conference]. Kiev, 2011, pp. 585. (in Russ.).

11. Navolokin N.A., Pavlova A.V. Biulleten' meditsinskikh Internet-konferentsii, 2012, no. 2, pp. 82-83. (in Russ.).

12. Navolokin N.A., Polukonova N.V., Maslyakova G.N., Bucharskaya A.B., Durnova N.A. Russian Open Medical Journal, 2012, vol. 1, no. 2, pp. 0203. URL: http://www.romj.org/2012-0203.

13. Gosudarstvennaia farmakopeia RF. [State Pharmacopoeia of the RF]. Moscow, 2008. 704 c. (in Russ.).

14. Patent 2482863 (RU). 2013. (in Russ.).

15. Zolotov Iu.A. Analiticheskaia khimiia: fragmenty kartiny. [Analytical chemistry: fragments of paintings]. Moscow, 1999, 144 p. (in Russ.).

16. Baitman T.P., Navolokin N.A. Biulleten' meditsinskikh internet-konferentsii, 2013, vol. 3, no. 2, pp. 374. (in Russ.).

17. Navolokin N.A., Polukonova N.V., Bucharskaya A.B., Maslyakova G.N. Vestnik rossiiskogo gosudarstvennogo meditsinskogo universiteta, 2012, no. 1, pp. 277-278.

18. Navolokin N.A., Polukonova N.V., Masliakova G.N., Bucharskaia A.B, Durnova N.A. Saratovskii nauchnomeditsinskii zhurnal, 2013, vol. 9, no. 2, pp. 213-220. (in Russ.).

19. Navolokin N.A., Polukonova N.V., Masliakova G.N., Skvortsova V.V., Baitman T.P., Bucharskaia A.B., Durnova N.A. Rossiiskii bioterapevticheskii zhurnal, 2013, vol. 12, no. 2, pp. 59-59a. (in Russ.).

Received February 28, 2013

Revised November 16, 2013

\footnotetext{
* Corresponding author.
} 
